\title{
Aspects of Chinese Cinema Today
}

\author{
By Toh, Hai Leong \\ Spring 1997 Issue of KINEMA
}

\section{THE TAIWANESE ANTONIONI: TSAI MING-LIANG'S DISPLACEMENT OF LOVE IN AN URBAN ENVIRONMENT}

NO, Tsai Ming-liang is not in fact Taiwanese. The bespectacled 40-year-old bachelor was born in Kuching, Sarawak (East Malaysia) and only came to Taiwan for a college education. After graduating with a degree in drama and film in Taiwan's University, he settled there and impressed critics with several experimental plays and television movies such as Give Me A Home (1988), The Happy Weaver(1989), My Name is Mary (1990), Ah Hsiung's First Love(1990). He made a brilliant film debut in 1992 with Rebels Of The Neon God and his film Vive l'amour shared Venice's Golden Lion for Best Film with Milcho Manchevski's Before The Rain (1994). Rebels of the Neon God, a film about aimless and nihilistic Taipei youths, won numerous awards abroad: Among them, the Best Film award at the Festival International Cinema Giovani (1993), Best Film of New Director Award of Torino Film Festival (1993), the Best Music Award, Grand Prize and Best Director Awards of Taiwan Golden Horse Festival (1992), the Best Film of Chinese Film Festival (1992), a bronze award at the Tokyo International Film Festival in 1993 and the Best Director Award and Leading Actor Award at the Nantes Festival des Trois Continents in 1994.(1)

For the sake of simplicity, he will be referred to as "Taiwanese", since he has made Taipei, (Taiwan) his home. In fact, he is considered to be among the second generation of New Wave filmmakers in Taiwan. It would also make Hsu Li-kong, the Vice-President of Taiwan's KMT-owned Central Motion Picture Corporation -- the astute and innovative elderly talent scout who also discovered Lee Ang (Pushing Hands, A Wedding Banquet Eat Drink Man Woman, Sense and Sensibility) -- happy for producing Tsai's first two acclaimed films.

It was at the 17th Hongkong International Film Festival in 1993 that Rebels was introduced to an international audience as a Special Presentation film. Those who saw the film were impressed. Later, the reticent Tsai and his shy, unknown lead actor, Lee Kang-sheng, attended a reception for Festival Guests hosted by the Urban Council Chairman. When I asked Tsai if the master of oblique displacement of emotion and narrative, Michelangelo Antonioni, was his greatest influence, he could only acknowledge with a few terse words, like the sparse dialogues in Rebels and Vive l'amour. Tsai, the talented filmmaker, looked more at ease creating his austere Bressonian images, with strong doses of Antonioni-esque bleak and spartan urban wasteland. Yet strangely, the two films are involving; emotionally, philosophically and spiritually.

His frequent collaborator, Lee was at a loss for words to describe his Method-acting technique. Like his mentor Tsai, he moves with fluid grace as the young dropout, Hsiao Kang, who is inextricably attracted to the thug, Ah Tze (Chen Zhao-jung) who had smashed up his father's taxi mirror. The self-taught actor whom Tsai discovered by chance on the street (Tsai picked Lee and Chen from the video arcades as both are street smart, naturalistic and "had the looks") did not speak in slick, yuppified Mandarin on the Lee Strasberg Method Acting. No, he is an instinctive actor who received his direction and inspiration from working closely with Tsai.

The Chinese title of Rebels of the Neon God (Qing Shaonian Nezha) translates as "The Young Nezha" (Na Cha). Nezha in Chinese mythology is a headstrong and rebellious Chinese deity famed for defying his parents. Shot in the colourful district of Taipei's Ximen Ting, the disturbingly bleak film was finished in two months. Seen in totality, Rebels is a study of a youth's longing to be free from loneliness, gloom and deprivation. It also deals with the apparent homosexual fascination and repulsion of Hsiao Kang for the thug, Ah Tze. Hsiao Kang (Lee Kang-sheng), a disaffected youth is perceived by his dotty mum as the reincarnation of the cantankerous boy-god Nezha. A preparatory student, Hsiao Kang, is unable to concentrate on his studies. In the film's ominous start he is more involved with a cockroach than by his homework. He spears the miserable bug on his compass, then chucks it out of the rain splattered window. When it flits back with the 
gust of wind, Hsiao Kang smashes the window, thus injuring his hand. He drops out of school, takes his tuition money and spends it wastefully. His incensed dad boots him out but leaves the door a little ajar.

Wandering aimlessly, Hsiao Kang chances upon a young hoodlum, Ah Tze, who rips off pay phones and vandalizes video arcades with his buddy, Ah Bing. Ah Tze's apartment is perpetually waterlogged and the lift always strangely stops at the haunted fourth level, as if to take in the ghostly inhabitants.

By the film's conclusion the protagonists have begun to haunt one another, especially for Hsiao Kang, who is both attracted and repulsed by Ah Tze's brutish ways but unable to befriend him. In his frustration an oblique homosexual transference takes place and turns inward, as Hsiao Kang's desire for the older chap becomes aggression and he smashes up Ah Tze's prized motorcycle by spraying "AIDS" across the petrol tank in revenge for the latter's smashing his father's taxi.

Ah Tze is enamoured of Ah Kui, a skating rink girl whom he dates and almost beds. When Ah and Ah Tze try to steal the computer chipboards from a video arcade they are beaten by gangster bouncers but only Ah Tze manages to escape with minor injuries. He brings Hsiao Kang home and tucks him under a poster of a life-sized pin-up girl and gets his girlfriend to comfort him.

Towards the conclusion, Hsiao Kang joins a telephone dating service. He wanders into the street as dawn breaks over a sleepy Taipei, bleakly pondering the precarious existence of the three male protagonists. However, there may still be hope left -- Hsiao Kang leaves the dating door open -- as did his father when Kang left home.

Tsai's ironically titled Vive l'amour (Aiqing Wansui) offers nothing but bitterness, emotional and spiritual vacuity, and unsatisfied homosexual longing. When this nihilistic film was shown in Singapore, the snobs who went to pay to see the sexy coupling of Yang Kuei-mei and Chen Zhao-jung, they were awfully disappointed and left with loud and often vulgar complaints about the film's incomprehensibility.

More terse and "silent" than the Rebels, Vive l'amour is about the elusive love and urban anomie among three inhabitants of contemporary Taipei in the 1990s. It is a painful but lovely evocation of the longing and yearning of the trio. Dialogue is so sparse (more sparse than in Robert Bresson's L'argent) that one gets a jolt when any of the characters speak. May (Yang Kuei-mei), is a real estate agent selling mostly empty condominium apartments and empty houses; Ah Jung (Chen Zhao-jung) is a freelance night-marketeer of designer Hongkong clothes. The emotionally fragile Ah Kang (again Lee Kang-sheng) sells urn space in a columbarium. Employing almost real time and a slow pace, the film is nevertheless involving and hypnotic, especially to those familiar with the work of Antonioni or Chantal Akerman. Vive l'amour is landmark filmmaking.

In the film May picks up Ah Jung in a coffeehouse one night and, like Marion Brando and Maria Schneider in Bernardo Bertolucci's Last Tango In Paris (1972), the couple have sex without any commitment in one of May's luxury condominiums. Unknown to them, Ah Kang has also set up "home" there, after discovering a forgotten key for the apartment door while delivering flyers advertising funeral space. Like Ah Kang, Ah Jung steals May's other key to the condominium and starts living there too. It is like a Tom-and-Jerry game of hide-and-seek, and the three develop the oddest of non-contact relationships: The gay Ah Kang watching fascinated their shackings -- falls in love with Ah Jung; the unsure but aggressive realtor May falls for Ah Jung who sees their sex trysts as nothing more than a physical encounter in his favour.

Vive l'amour is a sad commentary on the empty emotional and sexual lives of young Taiwanese who cannot love or feel any desire to be loved for all their faults and strengths. Ah Kang, the quintessential Tsai hero, is desperately looking for love -- in this case from the cold, feckless and physically heterosexual Ah Jung. May, though knowing her love for Ah Jung will come to nothing -- other than mere sensation followed by abandonment and betrayal -- will still have her last sex act of her life, still makes love to him. Sick of those meaningless trysts, she takes a cold, lonely walk through the maze of an incomplete public park, with nothing but empty benches and the fast rising materialistic, urban landscape of Taipei towering in the distance. Except for an old man as a distant companion, May sits alone on one of the cold grey benches, cries herself silly, lights a smoke, then cries again -- for the desperate loneliness of this thing called love. 
In the loud decibels of her wails and moans, one can hear the clanging of cement mixers, and the shuffling bustling noises of early morning joggers and commuters.

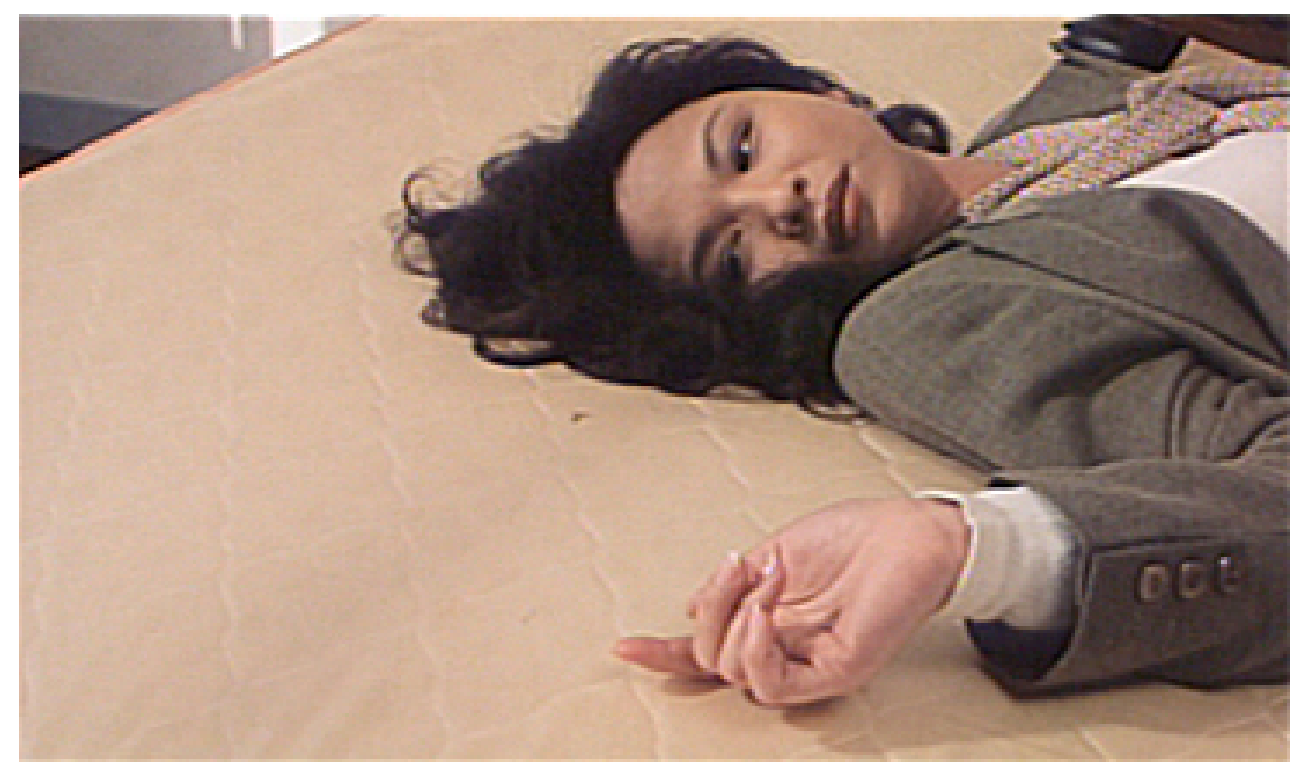

Figure 1: Vive l'amour (dir. Tsai Ming-liang, 1994)

Perhaps the most erotic scene in Vive l'amour is the last sexual union of May and Ah Jung with Ah Kang under their bed synchronizing his masturbation climax with the rhythm of the pair's final orgasm. This film doubtlessly occupies a special place in the annals of world cinema -- displaying among other things an Antonioni-inspired sense of the impossibility of love between man and woman and the Bressonian notion of absurdity and the meaninglessness of love, life and affirmation in this godless universe.

\section{A Swan Song: Decline of the Hongkong Cinema - Before 1997}

IN the early 1980s when I was reviewing Hongkong films for the Sunday Times in Singapore, I had the opportunity of viewing more than my fruitful share of films by New Wave luminaries like Allen Fong, Clara Law, Mabel Cheung, Ann Hui, Stanley Kwan, Jacob Cheung, Fannie Fang, Tsui Hark, Cheng Tokening, Patrick Tan, Yim Ho, most of whom cut their teeth making socially concerned cinéma-vérité, for television before branching out into cinema. The Hongkong film industry was then a force to be reckoned with, artistically and commercially.

The revitalising movement was carried on its slowly ebbing momentum until as late as 1993. Of course, since the New Wave films, being more intellectual, are meant more for the local yuppies and for Western tastes and international film festivals, the Hongkong triads were particularly interested in their productions. The highly commercial and lucrative films were, however, in their purview and close-guarding. The triads would go to all lengths to ensure that the superstars under their control in the 1980s (apparently, some wellknown actresses were even gang-raped and video-taped to force their compliance in acting for the sensational Category III sex films) work non-stop, with no respite and sometime he or she would hop from one set to another without so much as a change of fresh clothing!

Now the local triads have fanned out to Chinatowns overseas, largely due to the fact that when Hongkong is repossessed by the People's Republic of China, the death penalty for their activities -- from grand larceny to money laundering under the so-called film company's cover -- is mandatory in post-1997 Communistdominated Hongkong.

Domestic movie ticket sales since 1993 have shown a drastic halving -- from 33.6 million admissions (the Colony's population is about 6.2 million) to 14.1 million in 1995. When I was in the Colony in 1993, ticket 
prices averaged at HKD 40.00 (USD 5.20) compared to this year's average at HKD 55.00 (USD 7.15). In 1989, official figures showed a sale of 44.8 million tickets compared to 24.3 million in 1995.

The above figures are proof that the Hongkong film industry is in dire straits. In spite of several prominent movie moguls' prediction that business would pick up after 30th June 1997 with China's vast but largely (cinematically) untutored market to tap in, their statements sound hollow and the future looks grim.

To substantiate my pessimistic outlook, already Singapore's Eng Wah Film Organisation, touted as the leading distribution and exhibitor of Hongkong films since the booming 1980s, has shunned bringing in those Cantonese Mandarin-dubbed movies except for Stephen Chow's mo-lei-tau (nonsensical comedy) films and Jackie Chan's mega-hits, Rumble In The Bronx (1995) and First Strike-The Story of the CIA (1996). Even then, Chan hailed as Asia's last action hero, is aging and he has expressed desire to go behind the camera to direct. Chan's last two monster box-office hits were brought in by a new distribution and exhibition player in the Singapore film scene -- Golden Village Entertainment, a joint-venture between Raymond Chow's -- Jackie Chan's Golden Harvest (Hongkong) and Village Roadshow of Australia. Eng Wah have become a second, if not the third leader in the distribution and exhibition of Hongkong movies here. The strongly emerging second player is Overseas Movie Pte Limited, once a leftist film organisation with strong ties to Mainland China. The new management, however, has switched to a decidedly commercial orientation, bringing in more independent small-budget Hongkong movies. The only box-office draw to date has been Andrew Lau's triad youth films, Young And Dangerous I, II and III (1996).

Audiences have even been staying away from Andy Lau's romance films, Moment of Romance III (directed by ace filmmaker Johnny To who made the Story of Ah Long.

Maybe the decline is due to the Colony's exodus of its most famous mavericks -- John Woo who has absconded to Hollywood and made two action flicks there, Hard Target (1993) and Broken Arrow (1996); Tsui Hark, Asia's George Lucas and Ringo Lam. The charismatic Chow Yun Fat of A Better Tomorrow fame may soon be seen in Hollywood action movies perhaps with Sharon Stone -- meanwhile Chow is polishing up his English for his new working environment.

Even the infuriatingly oblique Godard of the East, Wong Kar wai (Days of Being Wild, Chungking Express) has been wooed by Quentin Tarantino, who has expressed his admiration for John Woo and Wong.

Hongkong "art" films -- Yim Ho's Homecoming (1986) and The Day The Sun Turned Cold (1995), Mabel Cheung's trilogy, The Illegal Immigrant (1985), An Autumn's Tale (1988) and 8 Taels of Gold (1990), Allen Fong's docudrama films, Father and Son (1981), Ah Yang (1984) and Just Like Weather (1987), Clara Law's Farewell, China (1991), Stanley Kwan's Rouge (1988), et al -- have been stretched to their artistic limits and very few good ones have been made after 1993 except for Yim Ho's 1995 achievement which was nominated for the Oscar's Best Foreign Language Film (but did not win) and Ann Hui's last year's back-to-form film, Summer Snow which won for its gentle veteran, Josephine Siao Fong Fong, the Berlin Film Festival's Best Actress award.

One of the best Hongkong films made in 1996 was Shu Kei's Hudumen, a sometimes charming comedy about a successful opera star (Josephine Siao again) beset with a defiant lesbian daughter, a cantankerous husband obsessively wanting to emigrate to Australia and longing for his "lost" son. Maverick Wong Kar-wai has stretched himself thin with his Fallen Angel (1995) and he looks westward now to refresh his preoccupations with jaded hit men out of step with the fast changing times.

Two concomitant factors contributing to the decline of Hongkong cinema are first, the crushing weight of rampant video piracy and second, the rise of the home entertainment system, owned by virtually all middleclass Hongkongers who prefer to watch films on videotape and laserdisc (and soon the remarkable DVD) at home.

Video piracy is the biggest headache that the filmmakers now face. The more blatant kind is the pirate attends an afternoon matinee, usually with very few people present, points his handycam at the screen and tapes the film off the screen (especially the Category III). It is that simple. With this "master" tape, he or she duplicates the movie by the dozen on slave VHS units. The sound quality is atrocious, with sometimes a cough here, a squelch there, or someone munching on biscuits, or somebody crossing the length of the front 


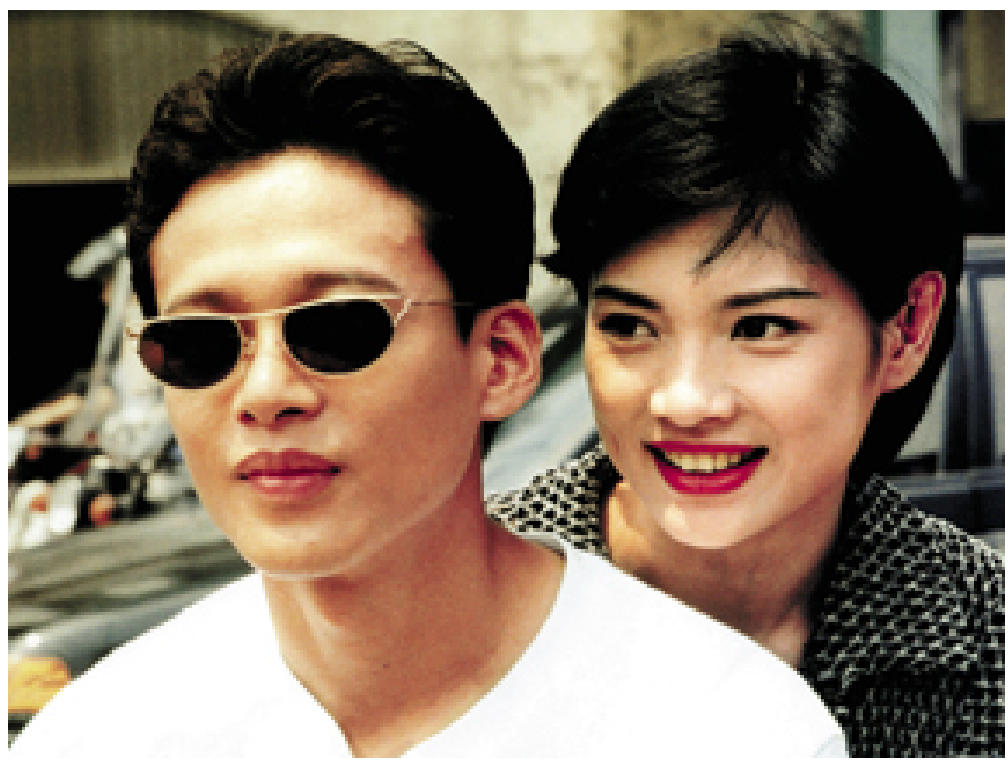

Figure 2: The River (dir. Tsai Ming-liang, 1997)

row with his or her head silhouetted against the screen. With video libraries dotted in every major sectors of the city, it is normal for a thrifty person to borrow several tapes and laserdiscs and make good quality copies of their favourites and share the cost among friends, without the hassle of going to the cinema.

In addition, home viewing is also encouraged by the cheaper price of original local Hongkong films on video of every conceivable genre. From a hefty and prohibitive price tag of HKD 800.00 (USD 104.00) to HKD 500.00 (USD 65.00) for first-time releases, one now can get well-made films like Remains of a Woman, Daughter of Darkness and other adult titles (Category IIB and III, the equivalent of the US NC-rating and X respectively) on video for as little as HKD 99.00 (USD 13.00) to HKD 140.00 (USD 18.20). Action-oriented video, can be bought at HKD 200.00 (USD 26.00) apiece, even for well-known titles.

So while Hong Kong's Jackie Chan or Ching Siu-tung's fantasy martial arts films are attracting audiences all over American and Canadian Chinatowns in droves to the cinemas, audiences are deserting the local cinemas in equal numbers. Thus it is very difficult for studio-backed producers to come up with HKD 10-15 million (USD 1.3-2 million) to make a movie now, with big and established names like Andy Lau, Leon Lai, Stephen Chow who are not abashed to ask over HKD 40 million (USD 5.2 million) in fees. In reality, this figure is a conservative estimate -- the cost of production has escalated to twice the amount -- up to HKD 30 million (USD 3.9 million) and with no guarantee of breaking even. Unless, of course, it is Jackie Chan and his favourite director Stanley Tong who are producing, directing and starring in the film.

This is a cold, harsh reality -- there will be no more days as in the glorious '80s when John Woo's A Better Tomorrow (1986) grossed HKD 30 million (USD 3.9 million) and outgrossed Hollywood imports. Now, the highly entertaining and popular Hollywood films grab the top spot. In late 1995 and 1996, the only Hongkong film to beat the Hollywood mainstays were the three sequels of The Young and Dangerous These three films were so successful that critics were inclined to equate this breakthrough with hope for local film production. There is an irony in this. Three good apples in a basket full of rotting ones do not make change in the already dying Hongkong cinema.

Undoubtedly, the "heroic" trio of films reflect the anxious, jittery times and spirit, especially of the youths, caught between the crossfire of hope and uncertainty about the Colony re-possession by the "Big Brother," well-known for brutalisation and repression of freedom and democracy. Perhaps because of the fresh cast of young faces, their naivety and easy exploitation by the triads, the collective Hongkong psyche is in full identification and sympathy with them.

There is a symbolic boxer's film Somebody Up there Likes Me (1996, directed by the master of melodrama, 
Johnny To) which tells in a schizoid mix of machoism and femininity the tear-jerking story of Ken, a talented kickboxer (Aaron Kwok). Critic Li Cheuk-to summed up this film most succinctly and yet alarmingly: "From his training to his miraculous success to his demise, his rise and fall mirrors the development of Hongkong cinema from the eighties to the present day." This suggests that To's contemporary cult film seals the final fate of Hongkong films and its industry with the death of Ken, the boxer-hero who takes on all the odds, even against the Japanese champion, and like a mythical Sisyphus struggles on, and defeats him before giving up the ghost.

There is no denying the Hongkong "golden goose" has laid its golden eggs in the 1980s. Like a lost love, the good times have gone and there can be no looking back.

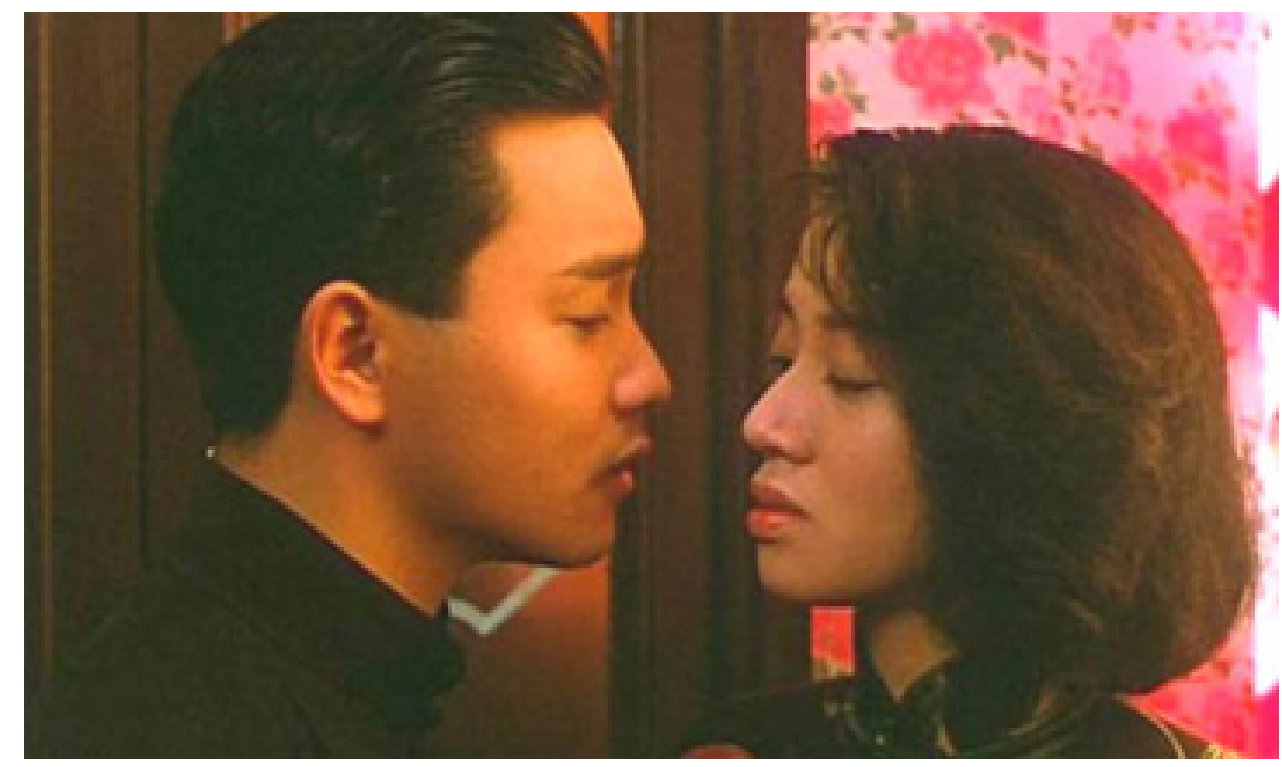

Figure 3: Rouge (dir. Stanley Kwan, 1988)

\section{Notes}

1. Editor's note: Tsai's most recent film, The River (He liu, 1997), which forms a loose trilogy with Rebels of the Neon God and Vive l'amour, won the Silver Bear Prize at the 47th Berlin in 1997.

\section{References}

\section{Tsai Ming-liang's films}

1988

Jia jiafu (TV-Film)

1989

Kuaile chefang (TV-Film)

Bu liao qing (TV-Film)

Haijiao tianya (TV-Film)

1990

Wode Yinwenmingzi jiao (TV-Film)

Mary (TV-Film)

Li xiangde Ganqingxian (TV-Film)

Ah xiongde chulian qingren (TV-Film) 
1991

Xiaohai (TV-Film)

1992

Qing shaonian nayu (Rebels of the Neon God)

1994

Aiqing wansui (Vive l'amour)

1995

My New Friends (Documentary)

1996

He liu (The River)

\section{Author Information}

TOH Hai Leong is a Singapore-based freelance film critic and filmmaker (Zombie Dogs, 2005) who writes for independent film publications such as Screen International and World Paper. He has covered the Hong Kong International Film Festival since 1985 and specializes in the cinemas of Hong Kong, Taiwan, China, Korea and Japan. 